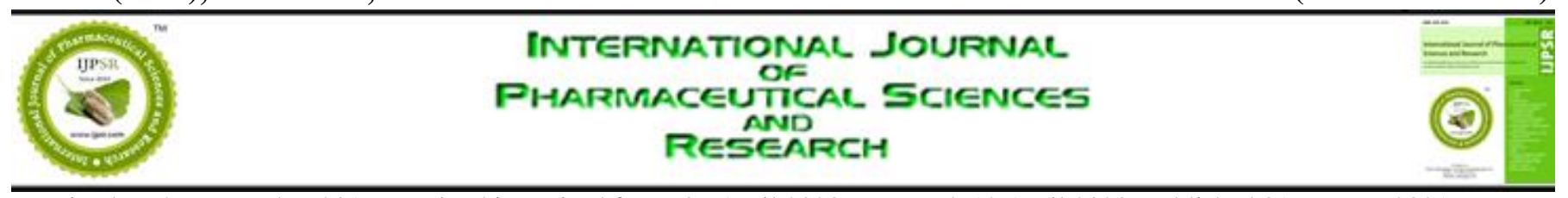

Received on 26 December 2019; received in revised form, 06 April 2020; accepted, 12 April 2020; published 01 January 2021

\title{
ANTIBACTERIAL ACTIVITY AND DNA BINDING PROPERTIES OF BIVALENT METAL COMPLEXES WITH CUMINALDEHYDE BENZOYLHYDRAZONE (CABH)
}

\author{
Y. B. Nagamani ${ }^{2}$, K. Hussain Reddy ${ }^{*}$, K. Srinivasulu ${ }^{1}$, D. Dhanalakshmi ${ }^{1}$ and K. Anuja ${ }^{1}$
}

Department of Chemistry ${ }^{1}$, Sri Krishnadevaraya University, Ananthapuramu - 515003, Andhra Pradesh, India.

Department of Chemistry ${ }^{2}$, N.S.P.R. Govt. Degree College (W), Hindupur - 515201, Andhra Pradesh, India.

Keywords:

DNA binding,

Antibacterial activity, Transition

metal complexes, Cuminaldehyde benzoylhydrazone

\section{Correspondence to Author:}

Dr. K. Hussain Reddy

UGC-BSR Faculty Fellow,

Department of Chemistry,

Sri Krishnadevaraya University,

Ananthapuramu - 515003, Andhra

Pradesh, India.

E-mail: khussainreddy@yahoo.co.in
ABSTRACT: Cobalt(II), nickel(II), copper(II) and zinc(II) complexes having the general formula $\mathrm{ML}_{2}$ (where, $\mathrm{L}=$ cuminaldehyde benzoylhydrazone, $\mathrm{CABH}$ ) have been synthesized and characterized based on mass spectra, molar conductivity, FT-IR and UV-Vis spectral data. The complexes are found to be non-electrolytes. FT-IR data suggest that the CABH acts as a uni-negative bidentate ligand. The copper complex is investigated using ESR spectroscopy at room temperature and liquid nitrogen temperature (LNT). The spin Hamiltonian, orbital reduction, and bonding parameters are calculated for the complex. The interactions of these complexes with calf thymus DNA have been investigated using absorption spectrophotometry. The zinc complex binds DNA more strongly than cobalt, nickel or copper complexes. The metal complexes are screened for their antibacterial activity against pathogenic bacterial strains. Complexes showed higher activity than the ligand. Copper complex shows more activity than any other complexes under investigation.
INTRODUCTION: Common spices have been used in Eastern culture as food flavors, perfumes, and medicines. Traditional Indian foods are enriched with a number of exotic spices and herbs. They have been recognized to possess biological activity beneficial to humans. Those spices containing medicinal compounds ${ }^{1}$ having carbonyl groups have evoked interest in the preparation of new ligands and their metal complexes. However, to the best of our knowledge hydrazones derived from the constituents of Indian spices have not so far been used to prepare transition metal complexes.

\begin{tabular}{|l|c|}
\hline QUICK RESPONSE CODE & DOI: \\
\hline DOI link: http://dx.doi.org/10.13040/IJPSR.0975-8232.12(1).188-95 \\
\hline
\end{tabular}

Cuminaldehyde is a naturally occurring compound. It is a benzaldehyde with an isopropyl group substituted in the 4-position. It is a constituent of several natural substances such as cumin, essential oils of eucalyptus, myrrh, cassia, etc. It has been shown that cuminaldehyde, inhibits the fibrillation of alpha-synuclein ${ }^{2}$, which is characterized by Lewy bodies, such as Parkinson's disease, dementia with Lewy bodies, and multiple system atrophy.

Hydrazones possess diverse biological and pharmacological properties ${ }^{3}$ such as antimicrobial, anti-inflammatory, analgesic, antifungal, antitubercular, antiviral, anticancer, antiplatelet, antimalarial, anticonvulsant, cardioprotective, antihelmintic, antiprotozoal, anti- trypanosomal, and antischistosomiasis. Hydrazones have been used in drug design as they act as ligands for metal complexes, organocatalysis, and synthesis of organic compounds. 
Benzhydrazide with diverse actions can be taken as a potential pharmacophore or as a lead compound. Looking into the biological activities of cuminaldehyde and benzhydrazide, it is considered worthwhile to investigate new hydrazone and its metal complexes.

Interaction of metal complexes with nucleic acids is an exciting area of research due to their potential use as drugs, tools for biochemical and biomedical applications in gene regulation. Considerable efforts are being made in our laboratories to investigate metal-DNA interactions ${ }^{4-6}$ and to develop drugs. Thus, looking to the importance of DNA binding agents with essential metal complexes for successful development of antimicrobial agents, herein we report the synthesis, characterization, DNA binding properties and anti bacterial activity of $\mathrm{Cu}$ (II), $\mathrm{Ni}$ (II), $\mathrm{Co}$ (II) and $\mathrm{Zn}(\mathrm{II})$ complexes of cuminaldehyde benzoylhydrazone (CABH).

\section{EXPERIMENTAL:}

Materials and Methods: Cuminaldehyde and benzhydrazide were purchased from Sigma Aldrich and used as such. $\mathrm{Co}(\mathrm{II}), \mathrm{Ni}(\mathrm{II}), \mathrm{Cu}(\mathrm{II})$ and $\mathrm{Zn}$ (II) metal salts were of analytical grade from Merck. All other reagents and solvents were purchased from commercial sources and were of analytical grade and were purified by distillation

Synthesis of Schiff Base Ligand: A solution of benzhydrazide $(2.3 \mathrm{~g}, 0.016 \mathrm{~mol})$ in $20 \mathrm{ml}$ methanol was added to a hot methanolic solution $(20 \mathrm{ml})$ of cuminaldehyde $(0.015 \mathrm{~mol}, 2.3 \mathrm{ml})$ in a $100 \mathrm{ml}$ round bottom flask. Few drops of glacial acetic acid were added to the reaction mixture. The contents were refluxed over a water bath for $2.5 \mathrm{~h}$ and cooled to room temperature. The light yellow colored compound was formed. It was filtered off, washed several times with hot water, and dried in vacuum. It was recrystallized from methanol. Yield: 72.33\%; M.P: $168-170{ }^{\circ} \mathrm{C}$ Chemical formula: $\mathrm{C}_{17} \mathrm{H}_{18} \mathrm{~N}_{2} \mathrm{O}$ Molecular Wt: 266.34. The synthesis of CABH is shown in Scheme 1.

Synthesis of Metal Complexes: To the ligand $(1.33 \mathrm{~g} ; 5 \mathrm{mmol})$ solution in $20 \mathrm{~mL}$ of methanol, the corresponding metal(II) chloride $(5 \mathrm{mmol})$ solution in $20 \mathrm{~mL}$ of aqueous methanol was added dropwise with constant stirring. The reaction mixture was refluxed for $1 \mathrm{~h}$ and cooled to room temperature. The metal complex precipitated was filtered, washed several times with cold ethanol, ether, and then dried in a vacuum over anhydrous $\mathrm{CaCl}_{2}$.



SCHEME 1: SYNTHESIS OF CUMINALDEHYDE BENZOYLHYDRAZONE (CABH)

Physical Measurements: The conductivity measurements were carried out on ELICO CM model 162 conductivity meter at $298 \pm 2$ in dry and purified dimethylformamide (DMF). ESI-Mass spectral data were obtained from Karunya Institute of Technology and Sciences, Coimbatore, India. The electronic spectra of metal complexes were recorded in DMF with an ELICO, SL-210 UVVisible spectrophotometer. The infrared spectra were recorded in the range 4000-400 $\mathrm{cm}^{-1}$ using Perkin Elmer spectrum 100 spectrometers in $\mathrm{KBr}$ discs. ESR spectra were recorded in solid-state and in DMF at $298 \mathrm{~K}$ and at liquid nitrogen temperature (L.N.T) on a Varian E-112 spectrometer with 100 $\mathrm{KHz}$ field modulation.
DNA Binding Experiments: DNA binding experiments were done in tris-buffer $(0.5 \mathrm{mM}$ $\mathrm{NaCl} / 5 \mathrm{mM}$ Tris- $\mathrm{HCl} ; \mathrm{pH}=7.0$ ). A solution of CTDNA in the buffer medium gave a ratio of UV absorbance at 260 and $280 \mathrm{~nm}\left(\mathrm{~A}_{260} / \mathrm{A}_{280}\right)$ of 1.81.9 , indicating that the CT-DNA was apparently free of proteins. The concentration of CT-DNA was estimated by using the $\varepsilon$ value of $6600 \mathrm{M}^{-1} \mathrm{~cm}^{-1}$ at $260 \mathrm{~nm}$, and the stock solution of DNA was always stored at $4{ }^{\circ} \mathrm{C}$. The electronic spectra of metal complexes in aqueous solutions were monitored in the absence and presence of CT-DNA. Absorption titrations were performed by maintaining the metal complex concentration $10 \times 10^{-6} \mathrm{M}$ and varying the nucleic acid concentration $\left(0\right.$ to $\left.7.36 \times 10^{-6} \mathrm{M}\right)$. 
Absorption titration experiments were carried out by varying the concentration of CT-DNA with each addition of $10 \mu \mathrm{L}$ DNA while the fixed metal complex concentration.

Antibacterial Activity: Antimicrobial screening of the ligand and the complexes was carried out using the agar-well diffusion method. The pathogenic bacterial strains were purchased from the National Chemical Laboratory (NCL), Pune, India. Antibacterial activity of compounds were screened against bacterial strains such as E. coli, $P$. aeruginosa, M. luteus, and B. substilis by using Agar well diffusion method. Nutrient agar (NA) plates were prepared using sterile nutrient agar medium was poured into sterile Petri-dishes and allowed to solidify. About $6 \mathrm{~mm}$ wells are made in each nutrient agar plate using a sterile cork borer.

Different concentrations of compounds (100, 200, and $300 \mu \mathrm{g} /$ well) were used to assess the dosedependent activity of the product. The metal complexes were dissolved in $10 \%$ dimethyl sulfoxide (DMSO), and micropipettes were used for the addition of compounds into the wells. Simultaneously the standard antibiotics (Ciprofloxacin used as a positive control) are tested against the pathogenic bacterial strains. Then the plates were incubated at $37{ }^{\circ} \mathrm{C}$ for $36 \mathrm{~h}$. After incubation, the zone inhibition of each well was measured, and the values were recorded. The experiments were carried out in triplicates with each compound, and the average values were calculated for determining the antibacterial activity.

\section{RESULTS AND DISCUSSION:}

Structural Characterization of New Ligand (CABH): The structure of the ligand has been confirmed by the analytical and spectral data. IR spectra: 3236, 3076, 2958, 1649 are assigned to $v(\mathrm{NH}), v(\mathrm{C}-\mathrm{H}$, aromatic $), v(\mathrm{C}-\mathrm{H}$, aliphatic $) v(\mathrm{C}=\mathrm{O})$ $\& v(\mathrm{C}=\mathrm{N})$ stretching vibrations respectively.

${ }^{1}$ H-NMR Spectra: (in $\mathbf{C D C l}_{3}$ solvent): The peaks at $\delta 10.364$ (singlet $1 \mathrm{H}) 8.413$ (singlet $1 \mathrm{H})(7.134$. 7.974) (multiplet 9H), 2.866 (quartet $1 \mathrm{H}$ ) 1.22 (doublets $6 \mathrm{H}$ ) are respectively assigned to $\mathrm{HC}=\mathrm{O}$, $>\mathrm{NH}, \mathrm{Ar}-\mathrm{H},>\mathrm{CH}$ and $\mathrm{CH}_{3}$ protons respectively.

Mass Spectra: The spectrum of $\mathrm{CABH}$ Fig. 1 shows a well-defined peak at $\mathrm{m} / \mathrm{z}=266.10$. This peak exactly corresponds to the molecular formula $\left(\mathrm{C}_{17} \mathrm{H}_{18} \mathrm{~N}_{2} \mathrm{O}\right)$ of the ligand. Fragmentation of the ligand is shown in Scheme 2.



FIG. 1: MASS SPECTRUM OF CUMINALDEHYDE BENZOYLHYDRAZONE



SCHEME 2: FRAGMENTATION PATTERN OF CUMINALDEHYDE BENZOYL HYDRAZONE

Based on spectral data, the structure of the new Schiff base is determined. 
Structural Characterization of the Metal Complexes: The analytical and molar conductance data of $\mathrm{Co}(\mathrm{II}), \mathrm{Ni}(\mathrm{II}), \mathrm{Cu}(\mathrm{II})$ and $\mathrm{Zn}(\mathrm{II})$ complexes are provided in Table $\mathbf{1}$.

TABLE 1: PHYSICOCHEMICAL AND ANALYTICAL DATA OF Cu (II) Ni (II) Co (II) AND Zn (II) COMPLEXES

\begin{tabular}{ccccc}
\hline S. no. & Complex & Colour (Yield \%) & ESI-MS* (F.W) & Molar Conductivity $\left(\boldsymbol{\Omega}^{-1} \mathbf{c m}^{2} \mathbf{m o l}\right.$ \\
\hline 1 & $\mathrm{Cu}(\mathrm{CABH})_{2}$ & Orange Red (72) & $595.3(595.5)$ & 6.43 \\
2 & $\mathrm{Ni}(\mathrm{CABH})_{2}$ & Orange Yellow (80) & $589.1(590.7)$ & 5.15 \\
3 & $\mathrm{Co}(\mathrm{CABH})_{2}$ & Light pink (87) & $588.6(590.9)$ & 19.68 \\
4 & $\mathrm{Zn}(\mathrm{CABH})_{2}$ & Light Yellow (79) & $596.2(597.4)$ & 4.50 \\
\hline
\end{tabular}

*Calculated values are given in parenthesis

The molar conductivity data suggest non- complexes, the IR spectrum of the free ligand was electrolytic nature ${ }^{7}$ of metal complexes.

FT-IR Spectra: In order to determine the binding mode of the $\mathrm{CABH}$ ligand to the metal in the compared with those of the complexes. Characteristic IR absorption bands of the ligand and its complexes are given in Table 2.

TABLE 2: IR DATA OF CABH LIGAND AND ITS COMPLEXES

\begin{tabular}{cccccc}
\hline CABH Ligand & $\mathbf{C u}(\mathbf{C A B H})_{\mathbf{2}}$ & $\mathbf{N i}(\mathbf{C A B H})_{2}$ & $\mathbf{C o}(\mathbf{C A B H})_{\mathbf{2}}$ & $\mathbf{Z n}(\mathbf{C A B H})_{\mathbf{2}}$ & Assignment \\
\hline 3236 & ---- & ----- & ---- & ----- & vN-H \\
1649 & ----- & ---- & ---- & vC $=\mathrm{O}$ \\
1649 & 1607 & 1604 & 1602 & 1605 & vC $=\mathrm{N}$ \\
1551 & 1516 & 1518 & 1510 & 1513 & vC $=\mathrm{C}(\operatorname{aromatic})$ \\
----- & 699 & 693 & 693 & 692 & M-O \\
----- & 533 & 525 & 528 & 508 & M-N \\
\hline
\end{tabular}

The IR spectrum of the ligand has some prominent bands due to $v_{\mathrm{N}-\mathrm{H}}, v_{\mathrm{C}=\mathrm{O}}$ and $v_{\mathrm{C}=\mathrm{N}}$ stretching modes. The first two bands disappeared in spectra of complexes due to enolization followed by complexation. The $v_{\mathrm{C}=\mathrm{N}}$ is shifted to a lower frequency in the spectra of all complexes suggesting the involvement of azomethine nitrogen in chelation ${ }^{8}$. IR data suggest that the ligand acts as mono anionic bidentate ligands in all metal complexes. The non- ligand bands in 692-699 and $508-533 \mathrm{~cm}^{-1}$ regions are tentatively assigned to $v_{(\mathrm{M}-\mathrm{O}) \text {, and }} v_{(\mathrm{M}-\mathrm{N})}$ vibrations ${ }^{9}$, respectively.

Electronic Spectra: Typical electronic spectrum of the copper complex is shown in Fig. 2. Electronic spectral data of metal complexes are summarized in Table 3.

A


FIG. 2: ELECTRONIC SPECTRA OF Cu(II) COMPLEX

(A) IN THE UV REGION AND (B) IN VISIBLE REGION

TABLE 3: ELECTRONIC SPECTRAL DATA FOR COMPLEXES OF CABH

\begin{tabular}{ccccc}
\hline S. no. & Complex & Wavelength* $(\mathbf{n m})$ & Frequency $\left(\mathbf{c m}^{-1}\right)$ & Assignment \\
\hline 1 & $\mathrm{Cu}(\mathrm{CABH})_{2}$ & 308 & 32,467 & CT- transition \\
& & 743 & 13,458 & d-d transition \\
2 & $\mathrm{Ni}(\mathrm{CABH})_{2}$ & 306 & 32,679 & CT transition \\
3 & $\mathrm{Co}(\mathrm{CABH})_{2}$ & 303 & 33,003 & CT transition \\
& & 531 & 18,832 & d-d transition \\
& & 981 & 10,193 & d-d transition \\
\hline
\end{tabular}

* Absorption maxima (peak) positions 
The electronic spectrum of Co(II)complex shows bands at 18,832 and $10,193 \mathrm{~cm}^{-1}$ in the visible region. These bands are respectively assigned to ${ }^{4} \mathrm{~A}_{2} \rightarrow{ }^{4} \mathrm{~T}_{1}(\mathrm{~F})$ and ${ }^{4} \mathrm{~A}_{2} \rightarrow{ }^{4} \mathrm{~T}_{2}$ electronic transitions in favour of tetrahedral structure. The peak due to ${ }^{4} \mathrm{~A}_{2} \rightarrow{ }^{4} \mathrm{~T}_{1}(\mathrm{P})$ is not appeared due to the masking/ concealing by intense CT band observed at 33,003 $\mathrm{cm}^{-1}$. In the visible spectrum of copper complex weak peak is observed at $13,458 \mathrm{~cm}^{-1}$ suggestings which is assigned to ${ }^{2} \mathrm{~T}_{2} \rightarrow{ }^{2} \mathrm{E}$ electronic transition, in favor of tetrahedral structures for the complex. No peak is observed for Ni complex in the visible region due to the domination of its $\mathrm{CT}$ band.

ESR Spectra of Copper Complex: ESR spectral data in solid-state and in DMF are given in Table 4. The $g$ values were computed from the spectrum using tetracyanoethylene (TCNE) free radical as the ' $\mathrm{g}$ ' marker.

TABLE 4: ESR SPECTRAL DATA $\dagger$ OF COPPER COMPLEXES

\begin{tabular}{|c|c|c|c|c|c|c|c|c|c|}
\hline \multicolumn{10}{|c|}{ In DMF at LNT } \\
\hline $\mathbf{g}_{\|}$ & $\mathbf{g}_{\perp}$ & g $_{\text {avg }}$ & $\mathbf{G}$ & $A_{\|} \times 10^{-5}$ & $A_{\perp} \times 10^{-5}$ & $\mathbf{K}_{\|}$ & $\mathbf{K}_{\perp}$ & $\lambda$ & $\alpha^{2}$ \\
\hline $\begin{array}{c}2.33 \\
(2.19)\end{array}$ & $\begin{array}{c}2.02 \\
(2.10)\end{array}$ & $\begin{array}{c}2.12 \\
(2.13)\end{array}$ & $\begin{array}{l}18.17 \\
(1.86)\end{array}$ & 0.00106 & 0.00033 & 0.996 & 1.12 & 565 & 0.352 \\
\hline
\end{tabular}

$\uparrow$ ESR data in DMF at Room Temperature are given in parenthesis

At Room Temperature in Solid State: The $\mathrm{g} \|$ and $\mathrm{g}_{\perp}$ values for $\mathrm{Cu}$ complex are respectively found to be 2.23 and 2.10 in DMF at room temperature. Kivelson and Neiman ${ }^{10}$ have reported that the $\mathrm{g} \|$ is less than 2.3 for covalent character and greater than 2.3 for the ionic character of the metal-ligand bonding. The $\mathrm{g} \|$ value suggests a covalent character for the complex. The trend, $\mathrm{g} \|>\mathrm{g} \perp>$ 2.0023 , suggesting that the unpaired electron predominantly in the $d_{x}{ }^{2}-y^{2}$ orbital ${ }^{10}$. The $g_{a v e}$ value for the complex suggests the presence of covalent character ${ }^{11}$ in M-L bond. The axial symmetry parameter $G$ is defined as,

$$
\mathrm{G}=\frac{\left[\mathrm{g}_{\|}-2.0023\right]}{\left[\mathrm{g}_{\Perp}-2.0023\right]}
$$

The calculated $G$ value for the complex is found to be 1.86. The $\mathrm{G}$ value is less than 4 for the complex, which indicates the absence of exchange coupling and misalignment of molecular axes.

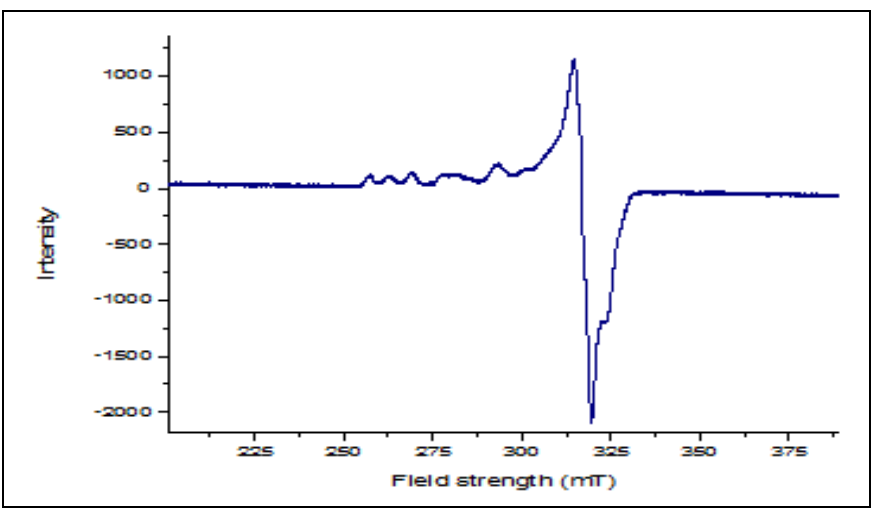

FIG. 3: ESR SPECTRUM OF COPPER COMPLEX IN DMF AT LNT
At Liquid Nitrogen Temperature in DMF: The typical ESR spectrum of $\mathrm{Cu}$ complex in DMF at Liquid nitrogen temperature (LNT) is shown in Fig. 3.

ESR spectra of complexes in DMF at liquid nitrogen temperature (LNT) exhibit well-resolved peaks at low field and at high field corresponding to $g_{\|}$and $g_{\perp}$, respectively. The spin Hamiltonian, orbital reduction, and bonding parameters of complexes are incorporated in Table 4 . The $A_{\|}$and $\mathrm{A} \perp$ are the separation between two adjacent $g_{\|}$and two adjacent $g \perp$ peaks, respectively (in $\mathrm{cm}^{-1}$ ). The orbital reduction parameters $(K \|, K \perp)$ are calculated using the following equations,

$$
\begin{aligned}
& \mathrm{g}_{\|}=\mathrm{g}_{\mathrm{e}}-\frac{8 \mathrm{~K}}{\Delta \mathrm{E}} \frac{{ }^{2} \frac{\lambda}{(\mathrm{d}-\mathrm{d})}}{\mathrm{g}_{\perp}}=\mathrm{g}_{\mathrm{e}}-\frac{2 \mathrm{~K}}{\Delta \mathrm{E}} \frac{\perp^{2} \frac{\lambda}{(\mathrm{d}-\mathrm{d})}}{}
\end{aligned}
$$

Hathaway pointed that for pure sigma bonding $K \|=$ $K \perp=0.77$ and for in-plane pi bonding $K \|<K \perp$, while for out-plane pi bonding $K \|>K \perp$. For the present complex, $K_{\|}$and $K \perp$ are 0.996 and 1.12, respectively. These values suggest the presence of in-plane pi bonding in the complex. The factor $\alpha^{2}$, which is usually taken as a measure of covalency is evaluated by the expression,

$$
\alpha^{2}=\mathrm{A} \| / p+\left(g_{\|}-2.0023\right)+3 / 7\left(g_{\perp}-2.0023\right)+0.004
$$

The $\alpha^{2}$ value for the complex (0.352), suggests the covalent nature of the metal ligand bond. The spin- 
orbit coupling constant $\left(\lambda=-565 \mathrm{~cm}^{-1}\right)$ for the complexes is very less than for the free metal ion ($829 \mathrm{~cm}^{-1}$ ). This observation suggests the covalent nature of metal-ligand bond ${ }^{10,11}$.

Based on physicochemical and spectral data, a general structure Fig. 4 is proposed for the complexes.

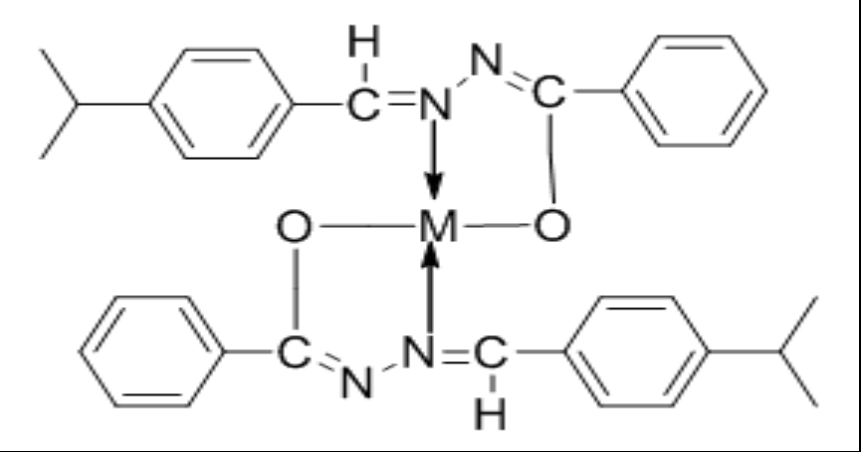

FIG. 4: PROPOSED STRUCTURE OF METAL COMPLEXES WITH CABH LIGAND

DNA Binding Studies: One of the important techniques to investigate the interaction of DNA with metal complexes is UV- Vis spectroscopy. Hence, the interaction of metal complexes with calf thymus DNA was monitored by UV-visible spectroscopy. Absorption spectra were recorded in the range of 200-500 $\mathrm{nm}$. Typical absorption
Spectra of $\mathrm{Co}(\mathrm{CABH})_{2}$ complex in the presence and in the absence of DNA are shown in Fig. 5.

Metal complexes exhibit an intense absorption band in high energy region, which is attributed to metal-ligand charge transfer (MLCT) transitions. The absorption spectra of complexes were compared in the absence and in the presence of CTDNA. The change in absorbance values with increasing amounts of CT-DNA was used to evaluate the intrinsic binding constant $\mathrm{K}_{\mathrm{b}}$, for the complexes. Based on the variation in absorption, the intrinsic binding constant or association constant $\left(\mathrm{K}_{\mathrm{b}}\right)$ of the metal complex can be calculated according to the Benesi-Hildebrand equation, modified by Wolfe et al. ${ }^{12}$

$$
[\mathrm{DNA}] /\left(\varepsilon_{\mathrm{a}}-\varepsilon_{\mathrm{f}}\right)=[\mathrm{DNA}] /\left(\varepsilon_{\mathrm{b}}-\varepsilon_{\mathrm{f}}\right)+1 / \mathrm{Kb}\left(\varepsilon_{\mathrm{b}}-\varepsilon_{\mathrm{f}}\right)
$$

Where, $\varepsilon_{\mathrm{a}}, \varepsilon_{\mathrm{f}}$, and $\varepsilon_{\mathrm{b}}$ correspond to $\mathrm{A}_{\text {observed }}$ $/$ complex], the extinction coefficient for the free metal complex, and the extinction coefficient for the metal complex fully bound to DNA, respectively, $\mathrm{Kb}$ represents the binding constant.

Electronic absorption spectral data upon addition of CT-DNA and binding constants of these complexes are given in Table 5.
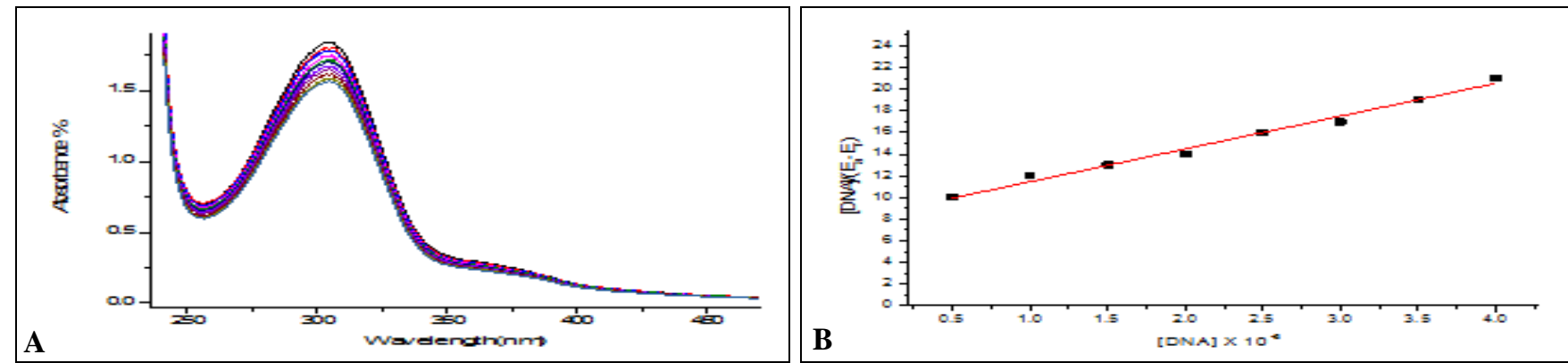

FIG. 5: (A) ABSORPTION SPECTRA OF CO(CABH $)_{2}$ COMPLEX IN THE ABSENCE(TOP CURVE) AND IN THE PRESENCE OF INCREASING CONCENTRATION OF DNA, (B) A PLOT [DNA]/ $\left(E_{A^{-}}-E_{F}\right)$ VS [DNA] $\times 10^{-6}$.

TABLE 5: ELECTRONIC ABSORPTION DATA UPON ADDITION OF C T -DNA TO THE COMPLEX

\begin{tabular}{|c|c|c|c|c|c|c|}
\hline \multirow[t]{2}{*}{ S. no. } & \multirow[t]{2}{*}{ Complex } & \multicolumn{2}{|c|}{$\lambda \max (\mathrm{nm})$} & \multirow[t]{2}{*}{$\Delta \boldsymbol{\lambda}$} & \multirow[t]{2}{*}{ H\% } & \multirow[t]{2}{*}{$\mathrm{K}_{\mathrm{b}} \times 10^{6}, \mathrm{M}^{-1}$} \\
\hline & & Free & Bound & & & \\
\hline 2 & $\mathrm{Ni}(\mathrm{CABH})_{2}$ & 304.5 & 302.5 & -2.0 & 50.05 & 0.38 \\
\hline 4 & $\mathrm{Zn}(\mathrm{CABH})_{2}$ & 305 & 306.5 & +1.5 & 90.05 & 16.40 \\
\hline
\end{tabular}

In the presence of increasing amounts of CT-DNA, the UV-visible absorption spectra of metal complexes [Except $\mathrm{Zn}(\mathrm{CABH})_{2}$ ] show significant hypsochromic shift (Blueshift) $\left(\Delta \lambda_{\max }=2.0-2.5\right.$ $\mathrm{nm}$ ) with increasing amounts of DNA. The calculated binding constants are found in the range
$0.38-16.4 \times 10^{6} \mathrm{M}^{-1}$. Metal complexes binding to DNA through intercalation usually result in hypochromism and bathochromism or hypsochromism ${ }^{13-15}$, while hyperchromism has been attributed to electrostatic attraction, hydrogen bonding and groove (minor or major) binding along 
the outside of DNA helix. High binding constants $\left(0.38-16.4 \times 10^{6} \mathrm{M}^{-1}\right)$ suggest that the complexes bind DNA via intercalation. The $\mathrm{Kb}$ values here are comparable to that reported for classical intercalator for ethidium bromide and $\left[\mathrm{Ru}(\mathrm{Phen})_{2} \mathrm{DPPZ}\right]^{2+}$ complex whose binding constants have been found to be in the order $10^{6}-10^{7}$. It is pertinent to note that the binding constant for $\mathrm{Zn}(\mathrm{CABH})_{2}$ complex is quite high. The increasing order of binding constant is found as shown below:

$$
\mathrm{Ni}(\mathrm{CABH})_{2}<\mathrm{Cu}(\mathrm{CABH})_{2}<\mathrm{Co}(\mathrm{CABH})_{2}<\mathrm{Zn}(\mathrm{CABH})_{2}
$$

The above order suggests that the $\mathrm{Zn}(\mathrm{CABH})_{2}$ complex binds DNA more strongly.
Antibacterial Activity Studies: All the metal complexes are screened for their antibacterial activity by using agar well diffusion method against pathogenic bacterial strains such as E. coli, $P$. aeruginosa, $M$. luteus, and $B$. substilis. Inhibition zones are determined in the presence of different amounts (100, 200, and $300 \mu \mathrm{g} /$ well) of complexes with reference to the positive control viz. ciprofloxacin. The diameters of inhibition of zone were measured with Vernier calipers in $\mathrm{mm}$, and its values are depicted in Table 6.

Antibacterial activities of metal complexes with $\mathrm{CABH}$ ligand are fairly comparable to the standard compound Fig. 6 as shown in bar graph.

TABLE 6: ANTIBACTERIAL ACTIVITY OF CABH LIGAND AND ITS METAL COMPLEXES AGAINST PATHOGENIC BACTERIA

\begin{tabular}{|c|c|c|c|c|c|c|}
\hline S. no. & Complex & Treatment & E. coli & P. aeruginosa & M. luteus & B. substilis \\
\hline 1 & S-Ciprofloxacin & $(5 \mu \mathrm{g} / \mu \mathrm{L})$ & 12.5 & 10.84 & 9.16 & 10.5 \\
\hline 2 & & $200 \mu \mathrm{g} / \mu \mathrm{L}$ & $2.63 \pm 0.17$ & $1.72 \pm 0.35$ & $2.34 \pm 0.55$ & $1.14 \pm 0.23$ \\
\hline \multirow[t]{3}{*}{3} & $\mathrm{Cu}-\mathrm{CABH}$ & $100 \mu \mathrm{g} / \mu \mathrm{L}$ & $5.73 \pm 0.28$ & $4.92 \pm 0.03$ & $4.02 \pm 0.30$ & $3.94 \pm 0.18$ \\
\hline & & $200 \mu \mathrm{g} / \mu \mathrm{L}$ & $7.82 \pm 0.43$ & $6.36 \pm 0.52$ & $5.45 \pm 0.08$ & $5.02 \pm 0.65$ \\
\hline & & $300 \mu \mathrm{g} / \mu \mathrm{L}$ & $8.35 \pm 0.61$ & $8.16 \pm 0.42$ & $7.35 \pm 0.23$ & $6.24 \pm 0.31$ \\
\hline 4 & & $300 \mu \mathrm{g} / \mu \mathrm{L}$ & $5.73 \pm 0.33$ & $5.03 \pm 0.45$ & $4.82 \pm 0.21$ & $4.36 \pm 0.61$ \\
\hline \multirow[t]{3}{*}{5} & $\mathrm{Co}-\mathrm{CABH}$ & $100 \mu \mathrm{g} / \mu \mathrm{L}$ & $1.57 \pm 0.15$ & $2.09 \pm 0.37$ & $2.37 \pm 0.67$ & $1.08 \pm 0.52$ \\
\hline & & $200 \mu \mathrm{g} / \mu \mathrm{L}$ & $2.86 \pm 0.06$ & $3.13 \pm 0.17$ & $2.58 \pm 0.26$ & $2.04 \pm 0.01$ \\
\hline & & $300 \mu \mathrm{g} / \mu \mathrm{L}$ & $4.22 \pm 0.36$ & $5.69 \pm 0.72$ & $4.18 \pm 0.32$ & $3.86 \pm 0.16$ \\
\hline \multirow[t]{2}{*}{6} & $\mathrm{Zn}-\mathrm{CABH}$ & $100 \mu \mathrm{g} / \mu \mathrm{L}$ & $3.62 \pm 0.17$ & $2.33 \pm 0.11$ & $1.86 \pm 0.66$ & $2.73 \pm 0.07$ \\
\hline & & $200 \mu \mathrm{g} / \mu \mathrm{L}$ & $4.54 \pm 0.38$ & $6.08 \pm 0.04$ & $2.36 \pm 0.42$ & $5.21 \pm 0.42$ \\
\hline
\end{tabular}

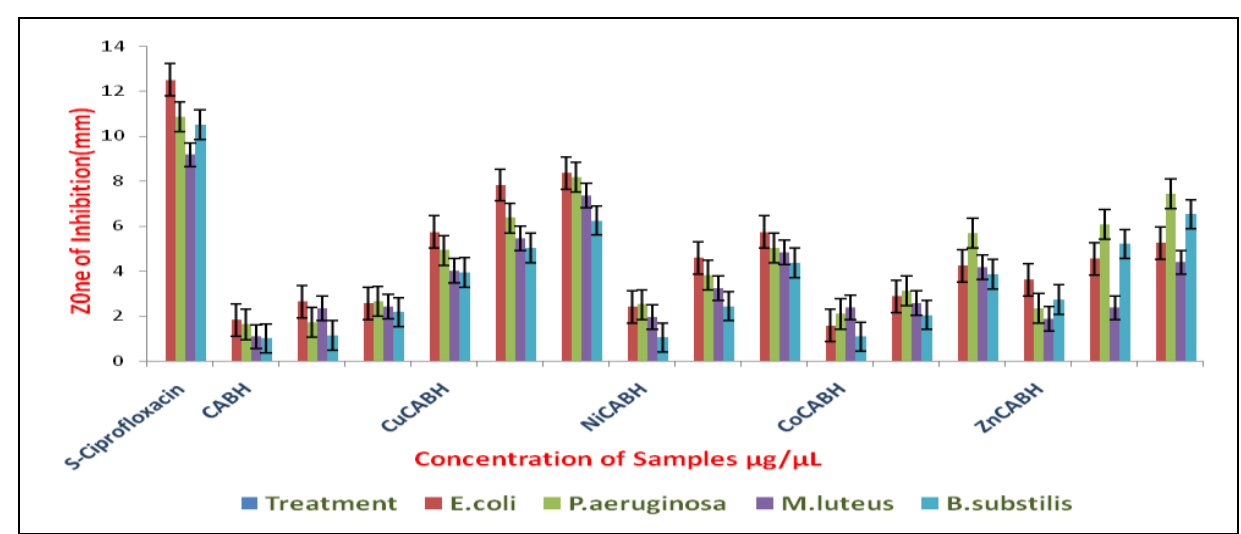

FIG. 6: GRAPHICAL REPRESENTATION OF ANTIBACTERIAL ACTIVITY OF METAL COMPLEXES AGAINST PATHOGENIC BACTERIAL STRAINS

Metal complexes exhibited higher antibacterial activity than the free ligand in the cases of Bacillus and $P$. aureoginosa in analogy with our previous observations ${ }^{5,16}$. Overtone's concept and Tweedy's chelation theory ${ }^{17}$ would explain the enhanced activity of complexes. According to the former concept, the lipid membrane surrounding the cell support the passage of only lipid-soluble materials, which means that lipid solubility is an important element for controlling antimicrobial activity. The polarity of a metal ion is greatly reduced on chelation. Delocalization of $\pi$-electrons over the whole chelating ring enhances the penetration ability of the complexes into the lipid membranes. 
The metal ion is released when the complex enters the cell. The ligand-free metal ion inhibits enzymes of the microorganisms ${ }^{18}$.

CONCLUSION: In the present study, a new ligand viz. cuminaldehyde benzoylhydrazone $(\mathrm{CABH})$ is synthesized and characterized based on spectral data. Cobalt(II), Nickel(II), copper(II), and zinc(II) complexes with $\mathrm{CABH}$ are synthesized and characterized based on physicochemical and spectral data. Current studies revealed that the complexes have general formula $\mathrm{ML}_{2}$ (where, $\mathrm{L}=$ $\mathrm{CABH})$. $\mathrm{CABH}$ acts as bidentate ligand towards metal ions. DNA interactions of metal complexes are uncovered using UV-Visible spectroscopy. The metal complexes are screened for their antibacterial activity. All complexes show higher activity than the metal free ligand; of all the complexes copper complex inhibits bacteria more strongly.

ACKNOWLEDGEMENT: KHR is thankful to UGC for the award of UGC-BSR Faculty Fellowship. The authors also thank UGC and DST for providing equipment facilities under SAP and FIST programs, respectively. The authors also Karunya Institute of Technology and Sciences, Coimbatore, for sending ESI-Mass spectral data of complexes.

CONFLICTS OF INTEREST: The authors declare that there is no conflict of interest regarding the publication of this article.

\section{REFERENCES:}

1. Shahverdi AR, Monsef-Esfahani HR, Tavasoli F and Mirjani R: Trans-cinnamaldehyde from Cinnamomum zeylanicum bark essential oil reduces the clindamycin resistance of Clostridium difficile in-vitro. Journal of Food Science 2007; 72: S055-S058.

2. Morshedi D, Aliakbari F, Tayaranian-Marvian, PanMontojo F and Pérez-Sánchez: Cuminaldehyde as the major component of $C$. cyminum, a natural aldehyde with inhibitory effect on alpha-synuclein fibrillation and cytotoxicity. J of Food Science 2015; 80: H2336-H2345.

3. Moksharagni B and Reddy $\mathrm{KH}$ : A review on pharmaceutical applications of lanthanide complexes with nicotinoyl and isonicotinoyl hydrazones. European Journal of Biomedical and Pharmaceutical Sci 2018; 58: 810-17.
4. Chandrasekhar S and Reddy KH: DNA binding and nuclease activity of structurally characterized copper(II) complex. International Journal of Pharmaceutical Sciences and Research 2016; 7: 4204-13.

5. Moksharagni B, Rishitha M and Reddy KH: Synthesis, DNA binding properties and antibacterial activity of lanthanide complexes with 2-benzoylpyridine isonicotinoylhydrazone. Indian J Chem 2017; 56: 232- 37.

6. Moksharagni B and Reddy KH: Spectral characterization and DNA binding properties of lanthanide(III) complexes with 2-acetylpyridine isonicotinoylhydrazone (APINH). Bull Chem Soc Ethiopia 2016; 30: 221-30.

7. Geary WJ: The use of conductivity measurements in organic solvents for the characterization of coordination compounds. Coord Chem Rev 1971; 7: 81-122.

8. Suseelamma A, Raja K and Reddy KH: Synthesis, characterization, DNA binding and nuclease activity of cobalt(II) complexes of isonicotinoyl hydrazones. Iran J Chem \& Chem Eng 2018; 37: 63-74.

9. Moksharagni B and Reddy KH: Synthesis, spectral characterization, DNA binding properties of lanthanide (III) complexes of 2-formylpyridine isonicotinoyl hydrazone. IJPSR 2017; 8: 3379-84.

10. Pragathi $M$ and Reddy KH: Synthesis, spectral characterization and DNA interaction of Copper(II) and nickel(II) complexes with unsymmetrical Schiff base ligands. Indian J Chem 2013; 52A: 845-53.

11. Reddy KH, Reddy PS and Babu PR: Synthesis, spectral studies and nuclease activity of mixed ligand copper (II) complexes of heteroaromatic semicarbazones/thiosemi carbazones and pyridine. Journal of Inorganic Biochemistry 1999; 77: 169-76.

12. Wolfe A, Shimer GH and Meehan T: Polycyclic aromatic hydrocarbons physically intercalate into duplex regions of denatured DNA, Biochemistry 1987; 26: 6392-96.

13. Kumar P, Gorai I, Santra MK, Mandal B and Manna D: DNA binding, nuclease activity and cytotoxicity studies of $\mathrm{Cu}$ (II) complexes of tridentate ligands. Dalton Trans 2012; 41: 7573-81.

14. Arjmand F, Parveen S, Afzal M and Shahid MJ: Synthesis, characterization, biological studies (DNA binding, cleavage, antibacterial and topoisomerase I) and molecular docking of copper(II) benzimidazole complexes, Photochem Photobiol B Biology 2012; 114: 15-26.

15. Sirajuddin $M$, Ali $S$ and Badshah A: Drug-DNA interactions and their study by UV-Visible, fluorescence spectroscopies and cyclic voltametry, Photochem. Photobiol. B Biology 2013; 124: 1-70.

16. Kasimbi D, Hussain Reddy K and Devanna N: Synthesis, spectral characterization and antibacterial activity of Copper(II) complexes of functionalized hydrazones. Asian J Chem 2019; 31: 1289-93.

17. Tweedy BG: Plant extracts with metal ions as potential antimicrobial agent. Phytopathology 1964; 55: 910-18.

18. Neelakantan MA, Esakkiammal M, Mariappan SS, Dharmaraja $\mathrm{J}$ and Jeyakumar T: Synthesis, characterization and biocidal activities of some Schiff base metal complexes. Indian J Pharm Sci 2010; 72: 216-22.

How to cite this article:

Nagamani YB, Reddy KH, Srinivasulu K, Dhanalakshmi D and Anuja K: Antibacterial activity and DNA binding properties of bivalent metal complexes with cuminaldehyde benzoylhydrazone (CABH). Int J Pharm Sci \& Res 2021; 12(1): 188-95. doi: 10.13040/IJPSR. 0975-8232.12(1).188-95.

All @ 2013 are reserved by the International Journal of Pharmaceutical Sciences and Research. This Journal licensed under a Creative Commons Attribution-NonCommercial-ShareAlike 3.0 Unported License.

This article can be downloaded to Android OS based mobile. Scan QR Code using Code/Bar Scanner from your mobile. (Scanners are available on Google Playstore) 